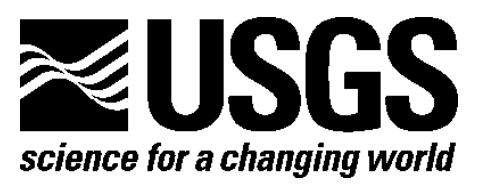

\title{
Soil Data for a Collapse-Scar Bog Chronosequence in Koyukuk Flats National Wildlife Refuge, Alaska, 2008
}

By Jonathan A. O'Donnell, Jennifer W. Harden, Kristen L. Manies, and M. Torre Jorgenson

Open-File Report 2012-1230

U.S. Department of the Interior

U.S. Geological Survey 


\section{U.S. Department of the Interior \\ KEN SALAZAR, Secretary}

\section{U.S. Geological Survey \\ Marcia K. McNutt, Director}

U.S. Geological Survey, Reston, Virginia: 2012

For more information on the USGS-the Federal source for science about the Earth, its natural and living resources, natural hazards, and the environment-visit http://www.usgs.gov or call 1-888-ASK-USGS

For an overview of USGS information products, including maps, imagery, and publications, visit http://www.usgs.gov/pubprod

To order this and other USGS information products, visit http://store.usgs.gov

Suggested citation:

O'Donnell, J.A., Harden, J.W., Manies, K.L., Jorgenson, M.T., 2012, Soil data for a collapse-scar bog chronosequence in Koyukuk Flats National Wildlife Refuge, Alaska, 2008: U.S. Geological Survey Open-File Report 2012-1230, 11 p.

Any use of trade, product, or firm names is for descriptive purposes only and does not imply endorsement by the U.S. Government.

Although this report is in the public domain, permission must be secured from the individual copyright owners to reproduce any copyrighted material contained within this report. 


\section{Contents}

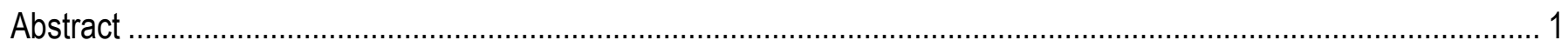

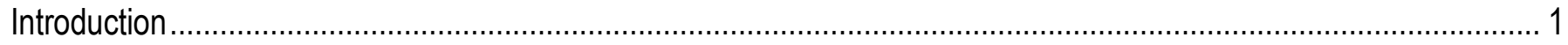

Study Region

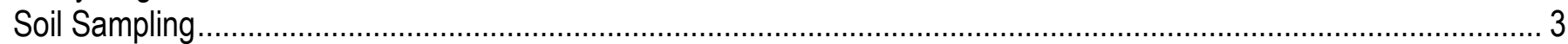

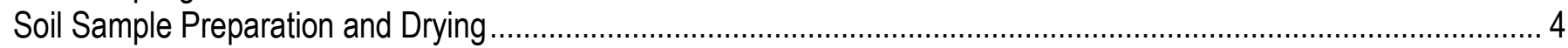

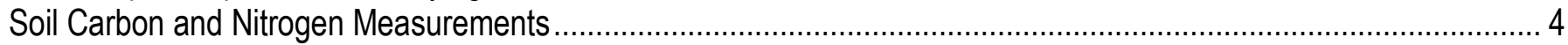

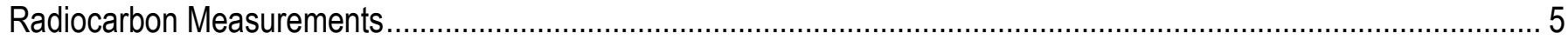

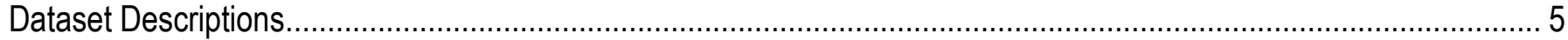

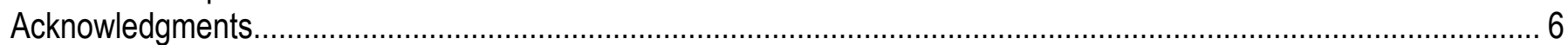

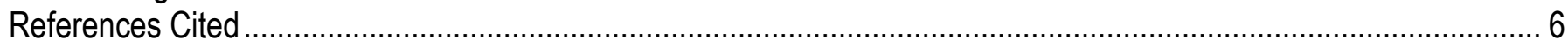

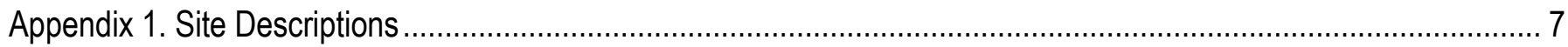

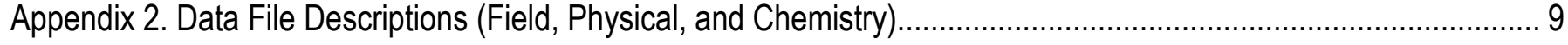

\section{Figure}

1. Map of Koyukuk Flats study site 


\title{
Soil Data for a Collapse-Scar Bog Chronosequence in Koyukuk Flats National Wildlife Refuge, Alaska, 2008
}

\author{
By Jonathan A. O'Donnell, Jennifer W. Harden, Kristen L. Manies, and M. Torre Jorgenson
}

\begin{abstract}
Peatlands in the northern permafrost region store large amounts of organic carbon, most of which is currently stored in frozen peat deposits. Recent warming at high-latitudes has accelerated permafrost thaw in peatlands, which will likely result in the loss of soil organic carbon from previously frozen peat deposits to the atmosphere. Here, we report soil organic carbon inventories, soil physical data, and field descriptions from a collapse-scar bog chronosequence located in a peatland ecosystem at Koyukuk Flats National Wildlife Refuge in Alaska.
\end{abstract}

\section{Introduction}

Peatlands comprise approximately 19 percent of the northern circumpolar permafrost region and store 277 petagrams of organic carbon (OC; Tarnocai and others, 2009), much of which is stored in frozen peat deposits (Tarnocai and others, 2007). Having developed over thousands of years since the last glaciation (Harden and others, 1992), northern peatlands have generally functioned as long-term sinks for atmospheric carbon dioxide $\left(\mathrm{CO}_{2}\right)$ and sources of atmospheric methane $\left(\mathrm{CH}_{4}\right),(\mathrm{Smith}$ and others 2004). However, climate-driven changes in permafrost extent or wildfire frequency could reduce the sink strength of northern peatlands (Turetsky and others, 2011) through the release of organic carbon stored in frozen or saturated peat (Turetsky and others, 2002; Dorrepaal and others, 2009). Permafrost degradation is of particular concern, given the recent acceleration of permafrost thaw in subarctic peatlands (Payette and others, 2004; Camill, 2005) and future projections of circumpolar permafrost thaw (Lawrence and others, 2008).

Here, we report soil OC inventories from a collapse-scar bog chronosequence located in a peatland ecosystem at Koyukuk Flats National Wildlife Refuge in Alaska. We sampled organic and mineral soils in 2008 in lowland black spruce (Picea mariana) stands and from collapse-scar bog sites that vary in age since permafrost thaw. These data were originally reported and used to parameterize a mass-balance model of peatland and permafrost OC dynamics in a study by O'Donnell and others (2012). Findings from this study indicate that deep OC stocks harbored in Holocene peatland deposits may be vulnerable to thaw and subsequent loss to the atmosphere as $\mathrm{CO}_{2}$ and $\mathrm{CH}_{4}$.

\section{Study Region}

We conducted our studies in the Koyukuk National Wildlife Refuge (NWR), one of the largest lowland basins in interior Alaska (fig. 1). Koyukuk NWR covers 14,160 square kilometers $\left(\mathrm{km}^{2}\right)$ of wetlands on the abandoned floodplains and drained thaw-lake basins adjacent to the Koyukuk River, and spans from the southern foothills of the Brooks Range to its confluence with the Yukon River near Galena, Alaska. Peat deposits at Koyukuk NWR are thick (1-4 meters) relative to other peatlands in 
Alaska and are advantageous for studying long-term OC accumulation rates. There are abundant thermokarst features in the region, with a range of post-thaw successional stages within close proximity of each other. The Koyukuk Flats study area (N. $65.19^{\circ}$, W. $155.36^{\circ}$; datum $=$ NAD83) is located about $50 \mathrm{~km}$ north of Galena and was accessed via floatplane. Logistical support was provided, in part, from the U.S. Fish and Wildlife Service located in Galena. From 1971 through 2000, the mean annual temperature in Galena averaged $-3.8^{\circ} \mathrm{C}$, with the annual maxima occurring in July $\left(20.4{ }^{\circ} \mathrm{C}\right)$ and minima in January $\left(-26.9^{\circ} \mathrm{C}\right)$ (Alaska Climate Research Center, http://climate.gi.alaska.edu/). During that same period, annual precipitation averaged 331 millimeters $(\mathrm{mm})$, with 40 percent of the annual precipitation falling from July through September. Snow typically covers the ground between the months of October and April, with an average maximum accumulation of 50 centimeters.

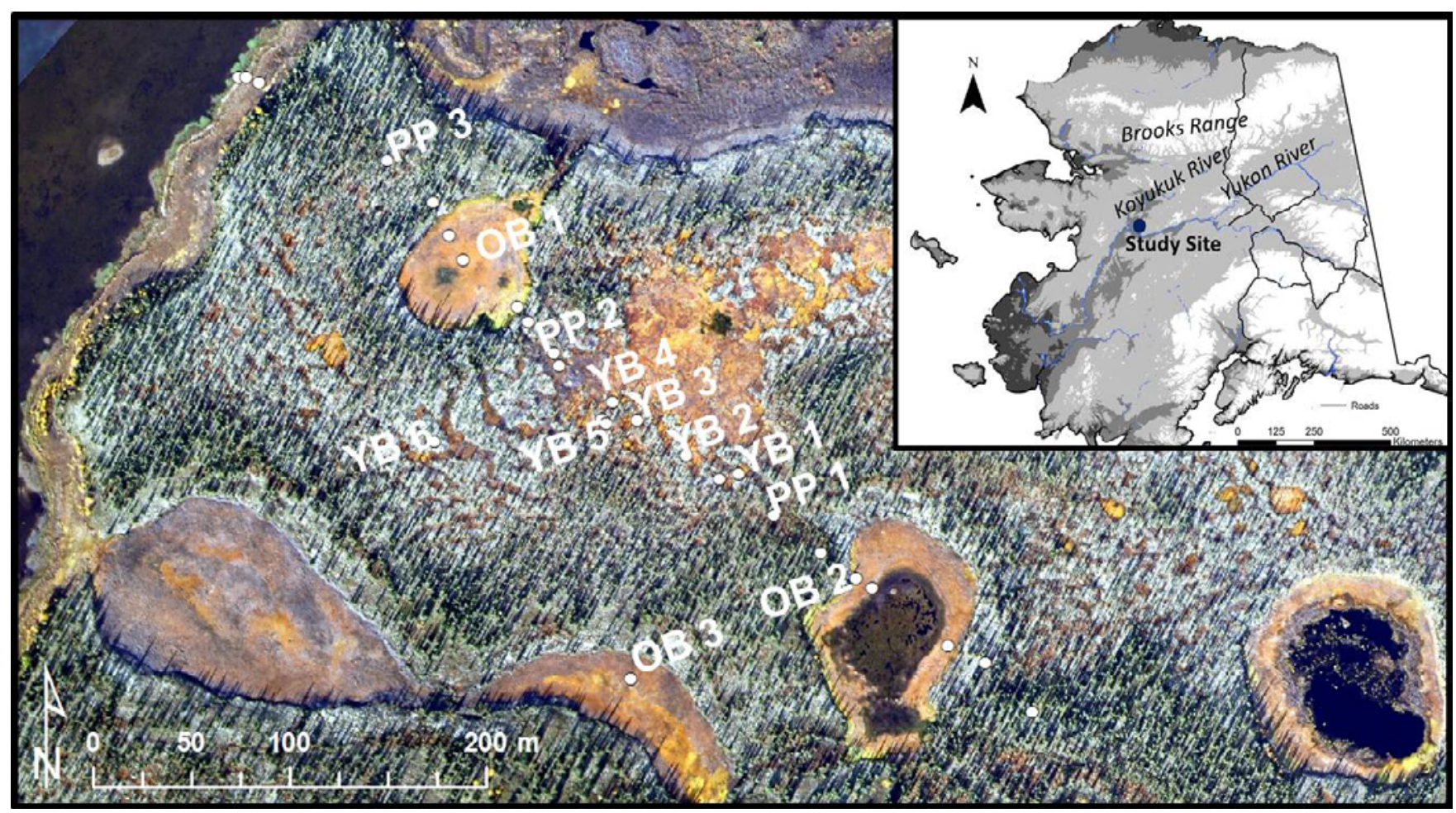

Figure 1. Map of Koyukuk Flats study site. Open circles represent the permafrost plateau (PP), young bog (YB) and old bog $(\mathrm{OB})$ study sites. Unlabeled circles represent additional survey points along the transect where site characteristics were described but peat samples were not collected. The map insert shows the location of Koyukuk Flats National Wildlife Refuge in Alaska.

To address our study objectives, we measured soil hydrologic, thermal, and OC dynamics across a permafrost thaw chronosequence. A soil chronosequence is a series of sites that have similar factors, such as climate, vegetation, slope, and parent material, but differ in age of the landform. Our chronosequence consisted of sites with permafrost plateaus, drying margins, and collapse-scar bogs that varied with respect to time of permafrost thaw and bog initiation (which we refer to as our young and old bog sites). Bog size was used as a proxy for age during bog selection. While all of our sites had similar climate, slope, and parent material, vegetation composition differed across landform ages, limiting our ability to isolate the effect of time from vegetation succession. The age of young bogs ranged from 31 to 61 years (yrs), as determined by the difference in mean age of mature black spruce 
trees on nearby permafrost plateau sites $(96 \pm 13 \mathrm{yr}, \mathrm{n}=9)$ and the age of dead black spruce trees found in collapse-scar bog features. Tree cores were obtained at breast-height, sanded upon returning to the laboratory, and then scanned at a resolution of 1200 dots per inch (dpi). These images were then imported into CooRecorder (V.7; http://www.cybis.se/forfun/dendro/), where the tree rings were counted manually. The age of two old bogs (400 and 1,215 yrs, respectively) were determined by radiocarbon $\left({ }^{14} \mathrm{C}\right)$ dating of organic matter at the interface of forest-derived and collapse-scar bogderived peat. Drying margin sites are transitional between the permafrost plateau and collapse bog sites, where the permafrost has begun thawing but subsidence has not yet occurred.

Vegetation composition varied with landscape position and collapse-scar bog age. Permafrost plateaus were dominated by black spruce and Sphagnum fuscum. We also commonly observed the presence of Andromeda polifolia, Ledum palustre, and Rubus chamaemorus. Drying Margins of collapse-scar bogs were dominated by Cladina spp. (C. stellaris, C. arbuscula, C. rangiferina, C. mitis) and L. decumbens. Young bogs were dominated by Eriophorum scheuchzeri and numerous Sphagnum spp., including S. jensenii, S. riparium, and S. lindbergii. In the old bogs, we primarily observed the mosses Sphagnum balticum and Sphagnum flexuosum and shrubs Andromeda polifolia and Oxycoccus microcarpus.

\section{Soil Sampling}

In August and September of 2008, we described and sampled soil horizons across a collapse-scar bog chronosequence following U.S. Department of Agriculture's Natural Resources Conservation Service (USDA-NRCS) (Soil Survey Staff, 1998) and Canadian (Soil Classification Working Group, 1998) methodologies. We sampled soil from replicate sites at permafrost plateaus $(\mathrm{n}=3$ sites; site ID = KFUW), Drying Margins of permafrost plateaus ( $n=3$; KFUD), young bogs $(n=3$; KFUY), intermediate bogs $(n=3$; KFUI), old bogs $(n=3$; KFUO) and a collapse-scar fen $(n=1$; KFUF). In collapse-scar bogs, we identified forest peat as organic matter derived from Sphagnum fuscum and Picea mariana ecosystems commonly observed on permafrost plateaus, and bog peat as organic matter derived from Sphagnum spp. commonly observed at the surface of young and old bogs. Fen peat horizons were typically composed of slightly decomposed moss and plant parts, such as Drepanocladus spp., Calliergon spp., Menyanthes trifoliata and Carex limosa. Mineral soil horizons (A, B, C) were characterized for texture and the presence of buried organic material. We also described and sampled lacustrine (or limnic) sediment below peat deposits. We used modified soil horizon codes according to the following scheme:

L Live moss, which are green and generally contain some leaf and needle litter.

D Dead moss, which is comprised of nondecomposed or slightly decomposed dead moss. The dead moss layer is characterized by fibric organic horizons that contain more moss than roots.

F Fibric (according to Canadian soil system) or fibrous organic layers, which vary in degree of decomposition but in which roots are more abundant than recognizable moss parts. In most cases, these layers would be considered Oi layers (U.S. soil system) or upper duff (U.S. Forest Service (USFS) soil system).

M Mesic (according to Canadian soil system) organic layers, which are moderately decomposed with few if any recognizable plant parts other than roots. M layers are generally Oe horizons (U.S. soil system) or lower duff layers (USFS soil system).

$\mathrm{H} \quad$ Humic (Canadian soil system) or sapric organic layers, which are highly decomposed. This layer generally smears upon squeezing and has no recognizable plant parts. $\mathrm{H}$ layers are generally $\mathrm{Oa}$ horizons (U.S. soil system) or lower duff (USFS soil system) layers. 
A Mineral soil that forms at the surface or below organic horizons (U.S. and Canadian soil system), with less than 20 percent organic matter, as judged in the field.

C Mineral soil that has been little affected by pedogenic processes (U.S. and Canadian soil system).

LN Lichen

La Limnic sediments

Frozen samples were described with a lower case " $\mathrm{f}$ " preceeding the horizon code. All horizons within a soil profile were sampled for bulk density, chemical analysis, and to determine moisture content.

At all sites, organic soil was sampled using a variety of soil knives, scissors and corers, in order to obtain a sample of known volume. For easily compressible, low-density samples, soil blocks were cut with scissors or serrated knives and dimensions were measured with a ruler. For less compressible shallow soils, samples were obtained with a 50-mm diameter corer rotated with a portable electric drill (Nadler and Wein, 1998). For deeper unfrozen peats we used a 70-mm diameter by 130-centimeter (cm)-long tube that was pushed and rotated into the peat by hand. A rubber cap was tightened over the corer to maintain a vacuum in the corer during extraction. At permafrost plateau sites, permafrost cores (up to 5 meters) were obtained using a SIPRE (Snow, Ice, and Permafrost Research Establishment) corer (7.5-cm inside diameter) with a Tanaka power head. We sampled peat until either a basal mineral or limnic horizon was encountered to allow calculation of OC stocks relative to a standard basal layer across sites. After collection, samples were placed in clean ziplock bags and shipped to U.S. Geological Survey (USGS) laboratories in Menlo Park, California.

\section{Soil Sample Preparation and Drying}

Upon arrival of samples to the laboratory, samples were inventoried using the field sheets. All samples were placed on open shelves in an isolated room and allowed to air dry to a constant weight, as determined by weights obtained at least one week apart. Temperature during air-drying ranged from 20 to $30{ }^{\circ} \mathrm{C}$. After air-drying, samples were oven dried for 48 hours in a forced-draft oven. Samples that were classified as organic soil horizons (moss, litter) were oven-dried at $65{ }^{\circ} \mathrm{C}$ to avoid loss or alteration of organic matter by oxidation or decomposition. The remaining samples were oven-dried at $105^{\circ} \mathrm{C}$.

After oven-drying, samples were thoroughly mixed, then split into subsamples for analysis and archiving (archive fractions of most of the samples described here are available by contacting J. Harden at the Menlo Park, Calif. office of USGS). These samples were then processed one of two ways, depending on horizon code. Mineral samples were gently crushed using a mortal and pestle, being careful to break only aggregates, and then sieved using a 2-mm screen. Soil particles not passing the 2$\mathrm{mm}$ screen were removed, weighed, and saved separately. Soil passing the 2-mm screen was then ground by hand using a mortar and pestle to pass through a 60 mesh $(0.246 \mathrm{~mm})$ screen. The ground material was mixed and placed in a labeled, glass sample bottle for subsequent analyses. Organic samples were weighed and roots greater than $1 \mathrm{~cm}$ in diameter were removed, weighed, and saved separately. The remaining sample was then milled in an Udy Corporation Cyclone mill (Ft. Collins, Colo.) to pass through a $0.5-\mathrm{mm}$ screen. The milled sample was thoroughly mixed and a representative sample placed in a labeled, glass sample bottle for analytical chemistry.

\section{Soil Carbon and Nitrogen Measurements}

A Carlo Erba NA1500 elemental analyzer (EA) was used to determine total C and total N. We analyzed soil samples for total carbon and nitrogen using a Carlo Erba NA1500 elemental analyzer. We 
assumed that total carbon was equal to organic carbon, given the low $\mathrm{pH}$ of soil samples $(\mathrm{pH}<6)$. Samples were combusted in the presence of excess oxygen. The resulting sample gasses were swept in a continuous flow of helium through an oxidation furnace, followed by a reduction furnace, to yield $\mathrm{CO}_{2}$, $\mathrm{N}_{2}$, and water vapor. Water was removed by a chemical trap, and $\mathrm{CO}_{2}$ and $\mathrm{N}_{2}$ were chromatographically separated before the quantification of C and N (Pella, 1990a, b).

All samples were compared to a main working standard, ethylene diamine tetra-acetic acid (EDTA), which has been calibrated through a set of international standards. The chemical formula for this compound corresponds to a $\mathrm{C}$ concentration of 41.09 percent and $\mathrm{N}$ concentration of 9.59 percent Additional working standards were analyzed as samples in all runs to check consistency and overall precision. Peach tree leaves (SRM-1547), issued by the National Institue of Standards and Technology (NIST), were included in runs comprised of organic soil. A marine sediment (MESS-1), issued by the Chemistry Division of the Canadian National Research Council, was included in runs comprised of mineral soils. Certified values for these standards were obtained from Becker (1990) and Govindaraju (1989), respectively.

\section{Radiocarbon Measurements}

We analyzed radiocarbon $\left({ }^{14} \mathrm{C}\right)$ content on a subset of soil samples to evaluate accumulation rates and turnover times of organic carbon, to determine the age of old bog formation, and to determine the basal age of peat across study sites. When possible, we collected Sphagnum spp. moss parts for ${ }^{14} \mathrm{C}$ analysis. To determine carbon accumulation rates in permafrost plateaus, we analyzed the ${ }^{14} \mathrm{C}$ content of 12 organic matter samples spanning depths of $2 \mathrm{~cm}$ to $405 \mathrm{~cm}$ below the ground surface. To age collapse-scar bogs, we analyzed ${ }^{14} \mathrm{C}$ content of organic matter at the interface of peat derived from forest and collapse-scar bog vegetation. When field sampling permitted, we also analyzed ${ }^{14} \mathrm{C}$ content of the lacustrine sediments (limnic, silt) beneath peat deposits. Samples were sent to the W.M. Keck C Cycle AMS Laboratory at the University of California Irvine for analysis as described in Southon and others (2004). Organic matter was combusted at $900{ }^{\circ} \mathrm{C}$ in evacuated, sealed quartz tubes in the presence of cupric acid $(\mathrm{CuO})$ and silver $(\mathrm{Ag})$ wire. Following cryogenic purification, carbon dioxide was reduced to graphite in a reaction at $500-550{ }^{\circ} \mathrm{C}$ using the sealed tube $\mathrm{Zn}$ reduction method (Xu and others, 2007). Radiocarbon data are reported as $\Delta^{14} \mathrm{C}$, or the per mil deviation of the ${ }^{14} \mathrm{C} /{ }^{12} \mathrm{C}$ ratio in the sample from that of an oxalic standard that has been decay corrected to 1950 (Stuiver and Polach, 1977). The $\Delta^{14} \mathrm{C}$ values we report have been corrected for mass-dependent fractionation using the in situ simultaneous AMS $\delta^{13} \mathrm{C}$ measurement. Age interpretation of organic matter samples with modern $\Delta^{14} \mathrm{C}$ signatures typically requires additional information, given the non-uniqueness of calculated turnover times and ages (Trumbore, 2000).

\section{Dataset Descriptions}

There are three separate downloadable files containing the soil data collected from the sites described in this report. Appendix 2 describes in detail the data within the following three spreadsheet files: (1) KoyukukFlats_Field, contains field descriptions, such as root abundance, color, and soil texture, of the sampled soils; (2) KoyukukFlats_Physical contains physical descriptions of the samples, such as volumetric field moisture and bulk density, (3) KoyukukFlats_Chemistry contains elemental C, elemental $\mathrm{N}, \Delta^{14} \mathrm{C}$ of soil organic matter, and loss on ignition (LOI) values. 


\section{Acknowledgments}

We thank Trish Miller, Misha Kanevskiy, and Kim Wickland for their assistance in the field and Pedro Rodriguez for his assistance in the lab. Xiaomei Xu analyzed soil samples for radiocarbon at the University of California Irvine. Support for this work was provided by the National Science Foundation collaborative grant EAR-0630249, the Institute of Northern Engineering at the University of Alaska Fairbanks, and the U.S. Geological Survey Global Change program.

\section{References Cited}

Alaska Climate Research Center, University of Alaska Fairbanks, available at http://climate.gi.alaska.edu.

Becker, D.A., 1990, Homogeneity and evaluation of the new NIST leaf certified reference materials, in Nuclear analytical methods in the life sciences: Gaithersburg, Md., National Institute of Standards, p. 571-577.

Camill, Philip, 2005, Permafrost thaw accelerates in boreal peatlands during late- $20^{\text {th }}$ century climate warming: Climatic Change, v. 68, issue 1-2, p. 135-152. (Also available at http://link.springer.com/article/10.1007\%2Fs10584-005-4785-y).

Damman, A.W.H., and French, T.W., 1987, The ecology of peat bogs of the glaciated Northeastern United States: A community profile: U.S. Fish and Wildlife Service 85 (7.16), 100 p. [Biological Report].

Dorrepaal, Ellen, Toet, Sylvia, van Logtestijn, R.S.P., Swart, E., van de Weg, M.J., Callahan, T.V., and Aerts, Rien, 2009, Carbon respiration from subsurface peat accelerated by climate warming in the subarctic: Nature, v. 460, doi:10.1038/nature08216, p. 616-619. (Also available at http://dx.doi.org/10.1038/nature08216).

Govindaraju, K., 1989, Compliation of working value and sample description for 272 geostandards: Geostandards Newsletter, v. 13, p. 1-113.

Harden, J.W., Sundquist, E.T., Stallard, R.F., and Mark, R.K., 1992,. Dynamics of soil carbon deglaciation of the Laurentide Ice Sheet: Science, v. 258, no. 5090, p. 1921-1924. (Also available at http://dx.doi.org/10.1126/science.258.5090.1921).

Lawrence, D.M., Slater, A.G., Romanovsky, V.E., and Nicolsky, D.J., 2008,Sensitivity of a model projection of near-surface permafrost degradation to soil column depth and representation of soil organic matter: Journal of Geophysical Research, v. 113, F02011, 14 p. (Also available at http://dx.doi.org/10.1029/2007JF000883).

Nadler, I.A., and Wein, R.W., 1998, A new forest floor corer for rapid sampling, minimal disturbance and adequate precision: Silva Fennica, v. 32, no. 4, p. 373-381.

O’Donnell, J.A., Jorgenson, M.T., Harden, J.W., McGuire, A.D., Kanevskiy, M.Z., Wickland, K.P., 2012, The effects of permafrost thaw on soil hydrologic, thermal, and carbon dynamics in an Alaskan peatland Ecosystems, v. 15, no. 2, p. 213-229. (Also available at http://dx.doi.org/10.1007/s10021011-9504-0).

Payette, Serge, Delwaide, Ann, Caccianiga, Michel, Beauchemin, Marco, 2004, Accelerated thawing of subarctic peatland permafrost over the last 50 years: Geophysical Research Letters, v. 31, L18208, 4 p. (Also available at http://dx.doi.org/10.1029/2004GL020358).

Pella, E., 1990a, Elemental organic analysis, Part 1-Historical developments: American Laboratory, v. 22, no. 2, p. 116-125.

Pella, E., 1990b, Elemental organic analyzer, Part 2:- State of the art: American Laboratory, v. 22, no. 12 , p. 28-32. 
Smith, L.C., MacDonald, G.M., Velichko, A.A., Beilman, D.W., Borisova, O.K., Frey, K.E.,

Kremenetski, K.V., and Sheng, Y., 2004, Siberian peatlands a net carbon sink and global methane source since the early Holocene: Science, v. 303, no. 5656, p. 353-356. (Also available at http://dx.doi.org/10.1126/science.1090553).

Soil Classification Working Group, The Canadian system of soil classification [3rd edition]: Ottawa, Ontario, Canada: NRC Research Press. 187 p.

Soil Survey Staff, 1998, Keys to soil taxonomy: Blacksburg, Va., Pocahontas Press, Inc., 599 p.

Southon, J., Santos, G., Druffel-Rodriguez, E., Trumbore, S., Xu, X., Griffin, Sheila, S., Shahla, A., and Mazon, M., 2004, The Keck Carbon Cycle AMS Laboratory, University of California, Irvine: Initial operation and a background surprise: Radiocarbon, v. 46, p. 41-49.

Stuvier, M., and Polach, H.A., 1977, Discussion: reporting of ${ }^{14} \mathrm{C}$ data: Radiocarbon, v. 19, p. $355-363$.

Tarnocai, Charles, Ping, C.L., and Kimble, John, 2007. Carbon cycles in the permafrost region of North America,in King, A.W., Dilling, L., Zimmerman, G.P., Fairman, D.M., Houghton, R.A., Marland G., Rose, A.Z., and Wilbanks, T.J., eds., 2007, The first state of the carbon cycle report (SOCCR)- The North American carbon budget and implications for the global carbon cycle, a report by the U.S. Climate Change Science Program and the Subcommittee on Global Change Research: Asheville, N. Car., National Oceanic and Atmospheric Administration, National Climatic Data Center, p. 127-138. Tarnocai, Charles, Canadell, J.G., Schuur, E.A.G., Kuhry, P., Mahtiova, G., and Zimov, S., 2009, Soil organic carbon pools in the northern circumpolar permafrost region: Global Biogeochemical Cycles, v. 23, GB2023, doi:10.1029/2008GB003327, 11p. (Also available at http://dx.doi.org/10.1029/2008GB003327).

Trumbore, Susan, 2000, Age of soil organic matter and soil respiration: radiocarbon constraints on belowground C dynamics: Ecological Applications, v. 10, p. 399-411.

Turetsky, Merritt R., Wieder, Kelman, Halsey, Linda, and Vitt, Dale, 2002, Current disturbance and the diminishing peatland carbon sink: Geophysical Research Letters, v. 29, no. 1526, doi:10.1029/2001GL014000, 4 p. (Also available at http://dx.doi.org/10.1029/2001GL014000).

Turetsky, M.R., Donahue, W.F., and Benscoter B.W., 2011, Experimental drying intensifies burning and carbon losses in a northern peatland: Nature Communications, v. 2, no. 514, doi:10.1038/ncomms1523. (Also available at http://dx.doi.org/10.1038/ncomms1523).

Viereck, L.A., Dyrness, C.T., Batten, A.R., and Wenzlick, K.J., 1992, The Alaska Vegetation Classification: U.S. Department of Agriculture Forest Service, Pacific Northwest Research Station, General Technical Report PNW-GTR-286, 142 p.

\section{Appendix 1. Site Descriptions}

This appendix describes the locations of each site sampled along the collapse-scar bog chronosequence at Koyukuk Flats National Wildlife Refuge. All study sites were accessed via floatplane from the village of Galena, Alaska.

- KFUW 1-The plot is located at coordinates N65.19612 ${ }^{\circ}, \mathrm{W} 156.63472^{\circ}$ (NAD83). The study plot is located in a poorly drained, mature black spruce stand with Ledum spp. and Sphagnum spp. The soil profile was sampled on August 25, 2008, by Jennifer Harden, Jonathan O'Donnell, and Misha Kanevskiy.

- KFUW 2-The plot is located at coordinates N65.19664 ${ }^{\circ}, \mathrm{W} 156.63704^{\circ}$ (NAD83). The study plot is located in a poorly drained, mature black spruce stand with Ledum spp. and Sphagnum spp. The soil profile was sampled on August 26, 2008, by Jonathan O'Donnell and Misha Kanevskiy. 
- KFUW 3-The plot is located at coordinates N65.19748 ${ }^{\circ}$, W156.63968 ${ }^{\circ}$ (NAD83). The study plot is located in a poorly drained, mature black spruce stand with Ledum spp. and Sphagnum spp. The soil profile was sampled on August 27, 2008, by Jennifer Harden, Jonathan O'Donnell, and Misha Kanevskiy.

- KFUO 3-The plot is located at coordinates N65.19703', W156.63840 (NAD83). The study plot is an old collapse-scar bog with Sphagnum spp. and the shrubs Andromeda polifolia and Oxycoccus microcarpus. The soil profile was sampled on August 27, 2008, by Torre Jorgenson, Jennifer Harden, and Jonathan O'Donnell.

- KFUO 4-The plot is located at coordinates N65.19587, W156.63376 ${ }^{\circ}$ (NAD83). The study plot is an old collapse-scar bog with Sphagnum spp. and the shrub Andromeda polifolia and some sedges. The soil profile was sampled on August 27, 2008, by Torre Jorgenson and Jennifer Harden.

- KFUO 5-The plot is located at coordinates N65.19526 $6^{\circ}$ W $156.63591^{\circ}$ (NAD83). The study plot is an old collapse-scar bog with Sphagnum spp. and the shrubs Andromeda polifolia and Oxycoccus microcarpus. The soil profile was sampled on August 28, 2008, by Torre Jorgenson and Trish Loomis (Miller).

- KFUI 1 - The plot is located at coordinates N65.19630', W156.63558 (NAD83). The study plot is an intermediate-aged collapse-scar bog with Sphagnum spp., Ledum decumbens, and Eriophorum scheuchzeri. The soil profile was sampled on August 25, 2008, by Jennifer Harden and Kim Wickland.

- KFUI 2-The plot is located at coordinates N65.19643', W156.63626 (NAD83). The study plot is an intermediate-aged collapse-scar bog with Sphagnum spp. and Andromeda polifolia. The soil profile was sampled on August 29, 2008, by Jonathan O'Donnell.

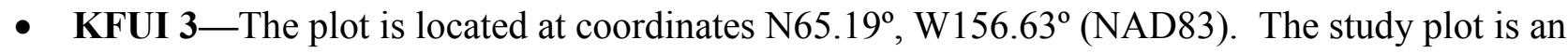
intermediate-aged collapse-scar bog with Sphagnum spp. and Ledum decumbens. The soil profile was sampled on August 26, 2008, by Jennifer Harden, Kim Wickland, Jonathan O'Donnell, and Misha Kanevskiy.

- KFUY 1-The plot is located at coordinates N65.19641', W156.63665 (NAD83). The study plot is a young collapse-scar bog with Sphagnum spp. The soil profile was sampled on August 28, 2008, by Jennifer Harden.

- KFUY 2-The plot is located at coordinates N65.19639, W156.63660 (NAD83). The study plot is a young collapse-scar bog with Sphagnum spp., Ledum decumbens, and Eriophorum scheuchzeri. The soil profile was sampled on August 26, 2008, by Jonathan O'Donnell, Jennifer Harden, and Kim Wickland.

- KFUY 3-The plot is located at coordinates N65.19626, W156.63510 (NAD83). The study plot is a young collapse-scar bog with Sphagnum spp. and Eriophorum scheuchzeri. The soil profile was sampled on August 28, 2008, by Jennifer Harden.

- KFUN 1-The plot is located at coordinates N65.19652 $2^{\circ}$ W156.63658 (NAD83). The study plot is a new collapse-scar bog with Sphagnum spp. The soil profile was sampled on August 26, 2008, by Jennifer Harden, Kim Wickland, and Torre Jorgenson.

- KFUD 1-The plot is located at coordinates N65.19558, W156.63214 (NAD83). The study plot is drying margin of a collapse-scar bog with Cladina spp. and Ledum decumbens. The soil profile was sampled on August 29, 2008, by Torre Jorgenson and Jonathan O'Donnell.

- KFUD 3-The plot is located at coordinates $\mathrm{N} 65.19^{\circ}, \mathrm{W} 156.63^{\circ}$ (NAD83). The study plot is drying margin of a collapse-scar bog with Cladina arbuscula. The soil profile was sampled on August 29, 2008, by Torre Jorgenson. 


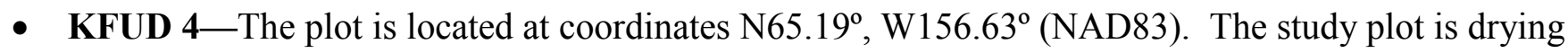
margin of a collapse-scar bog with Cladina arbuscula. The soil profile was sampled on August 29, 2008, by Torre Jorgenson.

- KFUF 1-The plot is located at coordinates N65.19, W156.63 (NAD83) and is a collapse-scar fen. Vegetation at the soil profile site was dominanted by Drepanocladus spp. and Menyanthes trifoliata. The soil profile was sampled on August 29, 2008, by Torre Jorgenson and Kim Wickland.

\section{Appendix 2. Data File Descriptions}

This appendix details what information is found within each of the columns of the three data files that accompany this report.

\section{KoyukukFlats_Field}

This file contains the field descriptions of the sampled soils and includes the following columns:

\begin{tabular}{|c|c|}
\hline Sample ID & $\begin{array}{l}\text { Sample identification: The first two letters in the sample labels represent the } \\
\text { region of study, Koyukuk Flats (KF). The next two letters represent the site } \\
\text { type. Site types include unburned wet (UW); unburned old bog (UO); } \\
\text { unburned intermediate bog (UI); unburned young bog (UY); unburned new } \\
\text { bog (UN); unburned drying margin (UD); and unburned collapse-scar fen } \\
\text { (UF). The number that follows these four characters indicates the profile } \\
\text { number. A decimal point separates the profile number from the basal depth of } \\
\text { the sample (in cm). }\end{array}$ \\
\hline Depth & Indicates the basal depth, in cm, of sampling increment. \\
\hline $\begin{array}{l}\text { Field Horizon } \\
\text { Code }\end{array}$ & $\begin{array}{l}\text { Horizon type of the sample, as defined in the field. } \mathrm{L}=\text { live moss; } \mathrm{LN}= \\
\text { lichen; } \mathrm{D}=\text { dead moss; } \mathrm{F}=\text { fibric organic matter }(\mathrm{OM}) ; \mathrm{M}=\text { mesic } \mathrm{OM} ; \mathrm{H}= \\
\text { humic } \mathrm{OM} ; \mathrm{A}=\mathrm{A} \text { mineral soil horizon; } \mathrm{C}=\mathrm{C} \text { mineral soil horizon; } \mathrm{La}= \\
\text { limnic horizon; and } \mathrm{X}=\text { unknown horizon. Ob represents a buried organic } \\
\text { horizon. A lower case " } \mathrm{f} \text { " before a horizon code indicates that the sample was } \\
\text { frozen when sampled. }\end{array}$ \\
\hline $\begin{array}{l}\text { Sample } \\
\text { Description }\end{array}$ & A brief description of the sample. \\
\hline Roots & $\begin{array}{l}\text { Root abundance and size using conventions of USDA-ARS (Soil Science } \\
\text { Staff, 1998). }\end{array}$ \\
\hline $\mathrm{pH}$ & $\begin{array}{l}\text { pH value of mineral soil measured in the laboratory. Deionized water was } \\
\text { added to create a soil slurry ( } 50 \text { percent soil, } 50 \text { percent water) prior to } \\
\text { measurement. }\end{array}$ \\
\hline Munsell Color & Munsell color value according to the Munsell Soil Color Chart. \\
\hline $\begin{array}{l}\text { Von Post or } \\
\text { Texture Class }\end{array}$ & $\begin{array}{l}\text { If organic soil, the classification using a modified version of the von Post } \\
\text { scale of humification (Damman and French, 1987). If mineral soil, the soil } \\
\text { texture class as described in the field followed conventions of USDA-ARS } \\
\text { (Soil Survey Staff, 1998). }\end{array}$ \\
\hline $\begin{array}{l}\text { Height above } \\
\text { mineral }\end{array}$ & $\begin{array}{l}\text { Height of each basal depth above the mineral soil boundary, in } \mathrm{cm} . \\
\text { Therefore, the bottom organic layer is at zero and all mineral horizons are } \\
\text { negative numbers. }\end{array}$ \\
\hline
\end{tabular}




\section{KoyukukFlats_Physical}

This file contains physical data such as bulk density, volumetric moisture content, and particle size analysis. Column definitions are as follows:

\begin{tabular}{|c|c|}
\hline Sample ID & $\begin{array}{l}\text { Sample identification: The first two letters in the sample labels represent the } \\
\text { region of study, Koyukuk Flats (KF). The next two letters represent the site } \\
\text { type. Site types include unburned wet (UW); unburned old bog (UO); unburned } \\
\text { intermediate bog (UI); unburned young bog (UY); unburned new bog (UN); } \\
\text { unburned drying margin (UD); and unburned collapse-scar fen (UF). The } \\
\text { number that follows these four characters indicates the profile number. A } \\
\text { decimal point separates the profile number from the basal depth of the sample } \\
\text { (in cm). }\end{array}$ \\
\hline Depth & Indicates the basal depth, in cm, of sampling increment. \\
\hline $\begin{array}{l}\text { Field Horizon } \\
\text { Code }\end{array}$ & $\begin{array}{l}\text { Horizon type of the sample, as defined in the field. } \mathrm{L}=\text { live moss; } \mathrm{LN}=\text { lichen; } \\
\mathrm{D}=\text { dead moss; } \mathrm{F}=\text { fibric organic matter }(\mathrm{OM}) ; \mathrm{M}=\text { mesic } \mathrm{OM} ; \mathrm{H}=\text { humic } \\
\mathrm{OM} ; \mathrm{A}=\mathrm{A} \text { mineral soil horizon; } \mathrm{C}=\mathrm{C} \text { mineral soil horizon; } \mathrm{La}=\text { limnic } \\
\text { horizon; and } \mathrm{X}=\text { unknown horizon. Ob represents a buried organic horizon. A } \\
\text { lower case " } \mathrm{f} \text { " before a horizon code indicates that the sample was frozen when } \\
\text { sampled. }\end{array}$ \\
\hline $\begin{array}{l}\text { Sample } \\
\text { Description }\end{array}$ & A brief description of the sample. \\
\hline Date Sampled & Date during which the sample was taken (month/day/year). \\
\hline Thickness & Thickness of soil horizon, in $\mathrm{cm}$. \\
\hline $\begin{array}{l}>2 \mathrm{~mm} \text { in } \\
\text { Sample }\end{array}$ & $\begin{array}{l}\text { Dry weight percent of soil particles not passing through a } 2-\mathrm{mm} \text { sieve after } \\
\text { gentle crushing. }\end{array}$ \\
\hline $\begin{array}{l}>1 \mathrm{~cm} \text { in } \\
\text { Sample }\end{array}$ & Dry weight percent of roots larger than $1 \mathrm{~cm}$ in diameter in the sample. \\
\hline $\begin{array}{l}\text { Bulk Density } \\
(<2 \mathrm{~mm})\end{array}$ & $\begin{array}{l}\text { Grams of oven-dried soil per cubic centimeter, with soil particles greater than } 2 \\
\text { mm and roots greater than } 1-\mathrm{cm} \text { diameter removed. }\end{array}$ \\
\hline Bulk Density & $\begin{array}{l}\text { Grams of oven-dried soil per cubic centimeter for the entire soil sample with no } \\
\text { fractions excluded. Calculated similarly to Bulk Density }(<2 \mathrm{~mm}) \text { except the } \\
\text { weight of particles greater than } 2 \mathrm{~mm} \text { and roots greater than } 1-\mathrm{cm} \text { diameter have } \\
\text { been included. }\end{array}$ \\
\hline $\begin{array}{l}\text { Volumetric } \\
\text { Field Moisture }\end{array}$ & The percent water in the sample, by volume. \\
\hline $\begin{array}{l}\text { Moisture in } \\
\text { Air-dry Sample }\end{array}$ & $\begin{array}{l}\text { Percent, by weight, of moisture remaining in a sample after air-drying to } \\
\text { constant weight as determined by subsequently oven-drying the sample. }\end{array}$ \\
\hline
\end{tabular}




\section{KoyukukFlats_Chemistry}

This file contains chemical data obtained from the elemental analyzer (EA) and the elemental analyzer mass spectrometer (EA/IRMS). Column definitions are as follows:

\begin{tabular}{|c|c|}
\hline Sample ID & $\begin{array}{l}\text { Sample identification: The first two letters in the sample labels } \\
\text { represent the region of study, Koyukuk Flats (KF). The next two letters } \\
\text { represent the site type. Site types include unburned wet (UW); } \\
\text { unburned old bog (UO); unburned intermediate bog (UI); unburned } \\
\text { young bog (UY); unburned new bog (UN); unburned drying margin } \\
\text { (UD); and unburned collapse-scar fen (UF). The number that follows } \\
\text { these four characters indicates the profile number. A decimal point } \\
\text { separates the profile number from the basal depth of the sample (in cm). }\end{array}$ \\
\hline Depth & Indicates the basal depth, in cm, of sampling increment. \\
\hline Field Horizon Code & $\begin{array}{l}\text { Horizon type of the sample, as defined in the field. } \mathrm{L}=\text { live moss; } \mathrm{LN}= \\
\text { lichen; } \mathrm{D}=\text { dead moss; } \mathrm{F}=\text { fibric organic matter }(\mathrm{OM}) ; \mathrm{M}=\text { mesic } \mathrm{OM} \text {; } \\
\mathrm{H}=\text { humic } \mathrm{OM} ; \mathrm{A}=\mathrm{A} \text { mineral soil horizon; } \mathrm{C}=\mathrm{C} \text { mineral soil horizon; } \\
\mathrm{La}=\text { limnic horizon; and } \mathrm{X}=\text { unknown horizon. Ob represents a buried } \\
\text { organic horizon. A lower case " } \mathrm{f} \text { " before a horizon code indicates that } \\
\text { the sample was frozen when sampled. }\end{array}$ \\
\hline Sample Description & A brief description of the sample. \\
\hline$\% \mathrm{C}$ & $\begin{array}{l}\text { Percent by weight of total carbon in an oven-dried soil sample with } \\
\text { material }>2 \mathrm{~mm} \text { or } 1-\mathrm{cm} \text { diameter removed. }\end{array}$ \\
\hline$\% \mathrm{~N}$ & $\begin{array}{l}\text { Percent by weight of total nitrogen in an oven-dried soil sample with } \\
\text { material }>2 \mathrm{~mm} \text { - or } 1-\mathrm{cm} \text { diameter removed. }\end{array}$ \\
\hline LOI & Loss-on-ignition value, in percent. \\
\hline $\begin{array}{l}\text { Bulk sample: Fraction } \\
\text { Modern }\end{array}$ & Fraction modern for bulk soil sample. \\
\hline Bulk sample: $\Delta^{14} \mathrm{C}$ & $\Delta^{14} \mathrm{C}$ value for bulk soil sample. \\
\hline Bulk sample: $\pm \Delta^{14} \mathrm{C}$ & Standard deviation of $\Delta^{14} \mathrm{C}$ value for bulk soil sample. \\
\hline Bulk sample: ${ }^{14} \mathrm{C}$ age & Radiocarbon age of bulk soil sample, in years before present. \\
\hline $\begin{array}{l}\text { Bulk sample: }{ }^{14} \mathrm{C} \text { age } \\
\text { error }\end{array}$ & Standard deviation of radiocarbon age for bulk soil sample, years. \\
\hline $\begin{array}{l}\text { Datable Material: } \\
\text { Fraction Modern }\end{array}$ & Fraction modern value for datable material (char, woody debris). \\
\hline $\begin{array}{l}\text { Datable Material: } \Delta \\
{ }^{14} \mathrm{C}\end{array}$ & $\Delta^{14} \mathrm{C}$ value for datable material (char, woody debris). \\
\hline $\begin{array}{l}\text { Datable Material: } \pm \Delta \\
{ }^{14} \mathrm{C}\end{array}$ & $\begin{array}{l}\text { Standard deviation of } \Delta^{14} \mathrm{C} \text { value for datable material (char, woody } \\
\text { debris). }\end{array}$ \\
\hline $\begin{array}{l}\text { Datable material: }{ }^{14} \mathrm{C} \\
\text { age }\end{array}$ & $\begin{array}{l}\text { Radiocarbon age of datable material (char, woody debris), years before } \\
\text { present. }\end{array}$ \\
\hline $\begin{array}{l}\text { Datable material: }{ }^{14} \mathrm{C} \\
\text { age error }\end{array}$ & $\begin{array}{l}\text { Standard deviation of radiocarbon age for datable material (char, woody } \\
\text { debris), years. }\end{array}$ \\
\hline Notes & Description of sample or datable material. \\
\hline
\end{tabular}

